\title{
Determinations of particle size distributions in natural waters use of Zeiss Micro-Videomat image analyzer
}

\author{
By M.C. Kavanaugh ${ }^{1}$, U. Zimmermann ${ }^{2}$ and A. Vagenknecht ${ }^{1}$ \\ 'Swiss Federal Institute for Water Resources and Water Pollution Control (EAWAG). \\ CH-8600 Dübendorf, Switzerland \\ ${ }^{2}$ Waterworks Zürich, Department of Limnology, Zürich, Switzerland
}

Manuscript received on 9 February 1977

\begin{abstract}
Use of a Zeiss Micro-Videomat electronic image analyzer for routine measurements of size distributions of particles found in natural waters greater than $0.3 \mu \mathrm{m}$ has been investigated.

Staining of particles with a solution of Gentiana-violet eliminated the multiple-count problem which has frustrated earlier attempts to use image analyzers for quantitative phytoplankton work. Concentration of samples from the lake water column was successfully achieved with an impact centrifuge. Losses of inorganic particles indicate that the centrifuge method must be evaluated on an individual case basis. Precision and accuracy of the Zeiss Micro-Videomat using either sedimentation (Utermöhl) or centrifugation for sample concentration were satisfactory for particles larger than $1 \mu \mathrm{m}$. The system appears promising for routine surveillance of raw water quality at water treatment plants, and performance of unit processes used for particulate removal, as well as for specific investigations of ecological phenomena in natural waters.
\end{abstract}

\section{Introduction}

It is well recognized that a quantitative description of size characteristics of particles found in natural waters provides important data for investigations of various physico-chemical and biological phenomena occurring in aqueous systems [1-4] as well as for selection and surveillance of unit processes used for suspended solids removal during water treatment [5]. While quantitative plankton studies will continue to rely on the established Utermöhl [6] method, súch microscopic counting is too tedious and time consuming for routine and regular determinations of the particle size distribution. Electronic particle counters offer the potential for rapid measurements. but their accuracy has been open to question [7].

Coulter Counters have been successfully employed for particle counting in many oceanographic investigations (eq. 8,9 ) but their application to fresh waters may be limited due to effects of sample handling during counting (suspension in high ionic strength solutions, breakage of aggregates passing through the orifice) on the distribution. Automatic or semiautomatic microscope image analyzers avoid these 
sampling measurement problems, but they have not find wide acceptance as phytoplankton counters apparently due to various counting errors, including multiple counts of single, irregularly shaped objects. A recent comparison of particle counts of natural phytoplankton samples from Lake Ontario determined with the inverted microscope and with two electronic counters, the Coulter Counter Model $\mathrm{B}^{1}$ ), and the Millipore Particle Measurement Computer System ${ }^{2}$ ) [7] concluded that the accuracy of the electronic counters was unacceptable using presently available sample preparation techniques.

This report describes the use of another image analyzer, the Zeiss-Videomat ${ }^{3}$ ) system, for particle size determination (PSD) of particles found in natural waters. New sample preparation techniques are presented, and the accuracy, precision, advantages and liabilities of the method are discussed.

\section{Objectives}

Use of electronic image analyzers for determination of the PSD for heterogeneous populations with a smallest dimension not less than $0.2 \mu \mathrm{m}$ (approximate lower limit of light microscope) requires solution of the multiple-count problem and development of improved concentration methods for dilute suspensions (total particle count less than $10^{5} \mathrm{ml}^{-1}$ ). Thus, the objectives of this investigation were as follows:

a) Development of a sample handling technique which reduces multiple counts.

b) Evaluation of the accuracy and precision of a Zeiss-Videomat semiautomatic image analyzer.

c) Development of improved sample concentration techniques and comparison with the established sedimentation (Utermöhl) method.

\section{Description of methods}

\subsection{Counting system}

The Zeiss Micro-Videomat II is a semiautomatic electronic image analyzer which can measure the total number count, total cross-sectional area, and the distribution of sizes of any particle population which can be seen with a light microscope. The basic instrument without software consists of a normal or inverted Zeiss Research Light Microscope, television video camera mounted on the microscopes, video screen, and electronic components for conversion and analysis of the light energy signal from the microscopes. Particles must exhibit sufficient contrast to permit electronic counting. The contrast range can be adjusted to match the reflectivity of the objects in the microscopic field. Inaccurate counts arise when contrast within an object varies, causing multiple counts. More detailed descriptions of the instrument are available in technical publications [10].

\footnotetext{
1) Coulter Electronic Inc., Hialeah, Florida, USA.

2) Millipore Corporation, Bedford, Mass. USA.

3) Carl Zeiss, Oberkochen, German Federal Republic.
} 


\subsection{Sample preparation}

\subsection{Contrast equalization}

Contrast irregularities in organic particles due to density variations within a cell were equalized with the addition of several drops of Gentiana-violet-solution per $100 \mathrm{ml}$ suspension. Electronic particle counts matched visual counts after 30 minutes staining time. This appeared to eliminate one cause of multiple counts.

\subsection{Sample fixation}

In the Utermöhl technique [6] J-KJ-solution is used both to fix and to improve sedimentation rates of the suspension. Unfortunately, the mixture of J-KJ-solution and Gentiana-violet-solution produced a precipitate which caused inaccurate particle counts. Samples were thus fixed in a $4 \%$ solution of formaldehyde and conserved when necessary at $3-4{ }^{\circ} \mathrm{C}$ in the dark. Determination of number counts and of the PSD at several intervals during conservation demonstrated that sample concentration should be conducted within 24 hours after addition of formaldehyde to avoid increased number counts due apparently to cell lysis.

\subsection{Sample concentration}

\subsection{Sedimentation}

Sample concentration was achieved by sedimentation for 24 hours using the Utermöhl [6] technique with or without J-KJ-solution depending upon the counting method. When necessary, samples were diluted to the final volume of $50 \mathrm{ml}$ to avoid overlapping of sedimented particles and the consequent false counts.

\subsection{Centrifugation}

A Shandon-Elliot slide centrifuge (Zytozentrifuge $\left.{ }^{4}\right)$ ), used to concentrate bacteria, blood cells and other biological materials directly on microscope slides, was evaluated as an alternate concentration technique to sedimentation. Particles suspended in the sample volume of up to $1.5 \mathrm{ml}$ impact on glass slides rotating at speeds up to $1,800 \mathrm{rpm}(450 \mathrm{~g})$ for durations up to 30 minutes.

The system has been successfully used for a wide range of biological particles, mostly various types of human or animal cells [11]. The efficiency of particle capture of the impact slide centrifuge, and effects on the particle size distribution were evaluated for a variety of suspensions by comparison with direct counts in a Bürker microscopic slide counting chamber.

\subsection{Counting procedure}

The electronic contrast discriminator of the Zeiss Micro-Videomat was adjusted to

4) Shandon Labortechnik GmbH, Frankfurt, German Federal Republic. 
its highest resolution, found by trial and error to be a setting of 100 arbitrary units on the grey discrimator scale. For each set of microscope optical settings, the instrument was calibrated using a micrometer, and verified with latex microspheres of known diameter. The calibration was checked intermittently.

The longest distance along a scan line served as a measuring parameter of the particle size. Size class intervals were selected such that the ratio of class width to the class arithmetic average size remained nearly constant, as suggested by Allen [12]. A geometric progression satisfies this criterion. Minimum discernible size was $0.3 \mu \mathrm{m}$, for a microscope enlargement of $400 \times$ (for inverted microscope), of $640 \times$ (for normal microscope) and total enlargement on video screen of about $940 \times$ resp. $1,500 \times$. For 17 size classes a count of at least 350 particles was required to give a representative particle count [13]. The necessary number of microscopic fields, selected in a constant but random pattern, were then counted.

Two scanning methods were employed. The prepared sample (stained and concentrated) was first observed at the lowest optical power, and large particles (size $>100 \mu \mathrm{m}$ ) counted. The count was completed at $400 \times$ and $640 \times$. Large, irregularly shaped phytoplankton and aggregates gave multiple counts at the higher magnification and manual corrections had to be made. Fortunately, the member of such particles was generally small, and did not substantially increase the time required for countings, which ranged from 1 to 2 hours per sample.

\subsection{Data reduction}

Using the appropriate conversion factors depending upon optics used, and initial volume of sample, the number of particles per volume of samples in each size class was computed. Assuming spherical geometry, the total particle surface area and

Table 1. Parameters of particle size distribution based on particle number counts determined with Zeiss Micro-Videomat.

\begin{tabular}{|c|c|c|}
\hline Parameter & Computational form & Significance \\
\hline $\begin{array}{l}\text { 1. First moment; } \\
\text { number length mean size }\end{array}$ & $\mathrm{d}_{\mathrm{NL}}=\frac{\sum \Delta \mathrm{N}_{\mathrm{i}} \mathrm{d}_{\mathrm{i}}^{*}}{\sum \Delta \mathrm{N}_{\mathrm{i}}}$ & Arithmetic average size \\
\hline 2. Second moment; dispersion & $\mathrm{M}_{2}=\frac{\sum \Delta \mathrm{N}_{\mathrm{i}} \mathrm{d}_{\mathrm{i}}^{* 2}}{\Sigma \Delta \mathrm{N}_{\mathrm{i}}}-\mathrm{d}_{\mathrm{NL}}^{2}$ & Measure of spread of distribution \\
\hline $\begin{array}{l}\text { 3. Number surface mean size } \\
\text { 4. Number volume mean size }\end{array}$ & $\begin{array}{l}\mathrm{d}_{\mathrm{NS}}=\left(\frac{\sum \Delta \mathrm{N}_{\mathrm{i}} \mathrm{d}_{\mathrm{i}}^{* 2}}{\sum \Delta \mathrm{N}_{\mathrm{i}}}\right)^{1 / 2} \\
\mathrm{~d}_{\mathrm{NV}}=\left(\frac{\sum \Delta \mathrm{N}_{i} \mathrm{~d}_{i}^{* 3}}{\sum \Delta \mathrm{N}_{\mathrm{i}}}\right)^{1 / 3}\end{array}$ & $\begin{array}{l}\text { Average sizes based on area and } \\
\text { volume, respectively: } \\
\text { sensitive to concentration of } \\
\text { larger }(\geq 10 \mu \mathrm{m}) \text { particles }\end{array}$ \\
\hline
\end{tabular}

Symbols for table 1:

$\mathrm{N}_{\mathrm{i}}=$ particle number per volume in $\mathrm{i}^{\text {th }}$ size class.

$d_{i}^{*}=$ arithmetic average size in $i^{\text {th }}$ class $\left(d_{i}^{*}=\frac{d_{j+1}+d_{i}}{2}\right)$. 
volume concentration was then calculated. Table 1 summarizes the computed parameters of the particle size distribution, which were used to compare distributions (see $[12,13]$ ).

\section{Results and discussion}

\subsection{Evaluation of impact centrifuge}

The efficiency of particle collection of the Shandon impact centrifuge was evaluated using both inorganic and organic particulate matter. Min-U-Sil 105), a granular silica sample with $99 \%$ of the particles having a diameter less than $10 \mu \mathrm{m}$, and a clay sediment-sample obtained near a gravel dredging zone in Lake Luzern, Switzerland, simulated samples of predominantly inorganic origin. Particulate matter of organic origin, phytoplankton and detritus, were obtained from a backwash water sample from the rapid sand filters at the waterworks Lengg, Zürich.

Total particle counts and the particle size distribution were determined with the Zeiss Counter directly in a Bürker counting slide (no sample concentration), and following sample concentration onto the microscope slide by centrifuging for 30 minutes at $1,800 \mathrm{rpm}$. The results are summarized in table 2.

Table 2. Efficiency of impact centrifuge for particle concentration.

\begin{tabular}{|c|c|c|c|c|}
\hline Suspension & $\begin{array}{l}\text { Maximum Size') } \\
(\mu \mathrm{m})\end{array}$ & $\begin{array}{l}\text { Direct } \\
\left.\text { Measurement }{ }^{2}\right) \\
(\text { Bürkerkammer) } \\
\left(\mathrm{ml}^{-1}\right)\end{array}$ & $\begin{array}{l}\text { Centrifuged } \\
\left.\text { Sample }^{2}\right) \\
\left(\mathrm{ml}^{-1}\right)\end{array}$ & $\%$ loss \\
\hline $\begin{array}{l}\text { MIN-U-SIL } 10 \mu \mathrm{m} \\
\left(\mathrm{SiO}_{2}\right)\end{array}$ & 10 & $3.08 \times 10^{7}$ & $3.24 \times 10^{6}$ & 89 \\
\hline $\begin{array}{l}\text { Lake } \\
\text { clay sediment sample } \\
(\sim 100 \% \text { inorganic })\end{array}$ & 20 & $1.18 \times 10^{7}$ & $3.17 \times 10^{6}$ & 73 \\
\hline $\begin{array}{l}\text { Backwash water, rapid } \\
\text { sand filter, } \\
\text { waterworks Lengg, Zürich }\end{array}$ & 30 & $3.06 \times 10^{6}$ & $3.02 \times 16^{6}$ & 2 \\
\hline
\end{tabular}

1) Maximum size: $99 \%$ of particles with size less than or equal to maximum.

2) Average of triplicates.

As can be seen, the inorganic materials exhibited high count losses $(\sim 80 \%)$, due apparently to agglomeration of smaller particles, as well as failure of particles to attach to the slide surface.

The particle size distributions of the backwash sample determined with and without the centrifuge are compared in a size frequency plot (number of particles per micron versus size) shown in figure 1 . Agreement between the two distributions is quite good. Small discrepancies between the dispersion and the number volume mean size

5) Producer: British Industrial Sand Ltd., Midland Sales Office, Church Bridge Industrial Estate, Oldbury (Narely, Worcester), England. 


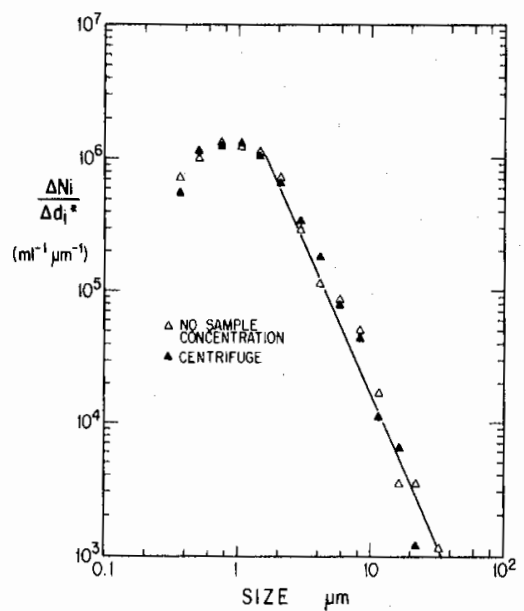

Figure 1. Particle size distribution of the backwash water samples from rapid sand filter at Water Treatment Plant Lengg, Zürich.

$\left(\mathrm{d}_{\mathrm{NV}}\right)$ as summarized in table 3, parameters most sensitive to concentrations of larger $(>10 \mu \mathrm{m})$ particles, fall within experimental error (see table 3 ).

Table 3. Comparison of particle size distribution parameters determined with and without centrifuge. Sample: Backwash water from rapid sand filter, Water Treatment Plant Lengg, Zürich.

\begin{tabular}{lcr}
\hline $\begin{array}{l}\text { Parameter of } \\
\text { Distribution }\end{array}$ & $\begin{array}{l}\text { Direct measurement } \\
\text { in Bürkerkammer }\end{array}$ & $\begin{array}{r}\text { Sample concentration } \\
\text { with cen trifuge }\end{array}$ \\
\hline Length mean size $(\mu \mathrm{m})$ & 3.0 & 2.8 \\
\hline Volume mean size $(\mu \mathrm{m})$ & 11.4 & 9.8 \\
\hline Dispersion & 24 & 20 \\
\hline Number of particles counted & 951 & 1567 \\
\hline
\end{tabular}

These results demonstrate that the Shandon impact centrifuge can be used successfully to concentrate particulate matter found in Zürichsee. Due to high losses of inorganic particles, however, the concentration technique may not be generally applicable. Evaluation of particle collection efficiency of the centrifuge will be required for each case.

\subsection{Accuracy of Zeiss Micro-Videomat}

The particle size distribution of a Zürichsee sample determined with an inverted light microscope was used as a 'standard' distribution to assess the accuracy of the electronic counter. One group of $50 \mathrm{ml}$ triplicate samples was fixed with J-KJsolution, allowed to settle for 24 hours, and the particle size distribution measured with the inverted microscope. A second group of $50 \mathrm{ml}$ triplicates was fixed with formaldehyde, stained with Gentiana-violet-solution, and allowed to settle for 24 hours. The distribution of particle sizes in the settled volume $(\sim 2 \mathrm{ml})$ of each sample was then determined with the Zeiss Micro-Videomat mounted on the inverted microscope. 
The average frequency distribution for each group of triplicates is shown in figure 2. The PSD determined microscopically is satisfactorily described by a hyperbolic distribution [14], up to about $15 \mu \mathrm{m}$. Above this size, the distribution exhibits a truncation, a distribution characteristic also reported for particulate samples from the open oceans $[2,14,15]$. The Videomat results also follow the hyperbolic distribution above the $1 \mu \mathrm{m}$ size limit. However, the PSD of the colloidal fraction $(0.3 \mu \mathrm{m}$ $<\mathrm{d}^{*}<1 \mu \mathrm{m}$ ) deviates substantially from the hyperbolic form, and from the assumed accurate results of the microscopic count. Two additional sets of triplicate measurements, using the same procedure as described, also exhibited this deviation in the colloidal range.

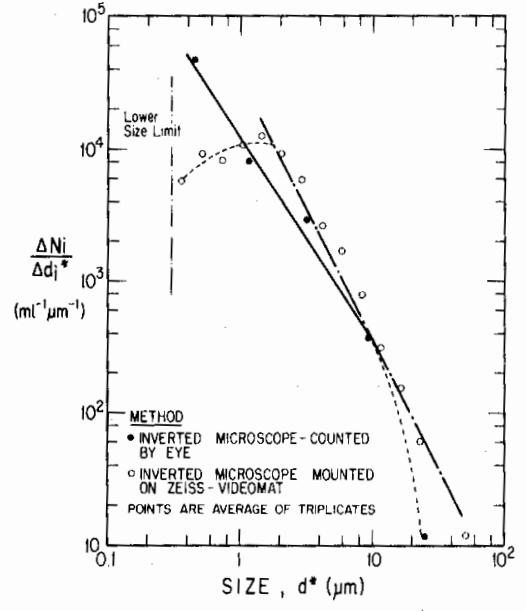

Figure 2. The average frequency distribution of Zürichsee samples (inlet of Water Treatment Plant Lengg, Zürich).

As is seen in figure 2, the Videomat tends to underestimate the particle counts below $1 \mu \mathrm{m}$ and overestimate above this limit. The effects of these errors on the parameters of the size distribution are shown in table 4 . The errors of the Videomat count below $1 \mu \mathrm{m}$ produce a larger number mean diameter, but variations in the dispersion of the distribution and the number volume mean diameter, parameters which are most sensitive to the concentration of larger particles, are within experimental error and statistically insignificant $(\mathrm{p}=0.95)$.

Table 4. Accuracy of particle counts using Zeiss Videomat. Sample from Zürichsee, 17.11.75 (depht $=34$ $\mathrm{m}$, minimum size $=0.3 \mu \mathrm{m}$ ).

\begin{tabular}{|c|c|c|c|c|c|}
\hline Method & $\begin{array}{l}\text { Total } \\
\left.\text { number }{ }^{1}\right) \\
\left(\mathrm{ml}^{-1}\right)\end{array}$ & $\begin{array}{l}\text { Number } \\
\text { length mean } \\
\text { diameter } \\
(\mu \mathrm{m})\end{array}$ & $\begin{array}{l}\text { Number } \\
\text { volume mean } \\
\text { diameter } \\
(\mu \mathrm{m})\end{array}$ & Dispersion & $\begin{array}{r}\text { Coefficient } \\
\text { of } \\
\text { hyperbolic } \\
\text { distribution }\end{array}$ \\
\hline $\begin{array}{l}\text { Sedimentation } \\
\text { microscopic counts }\end{array}$ & $3.60 \times 10^{4}$ & 2.5 & 10.5 & 22.6 & 1.5 \\
\hline $\begin{array}{l}\text { Sedimentation, } \\
\text { Videomat }\end{array}$ & $3.91 \times 10^{4}$ & 3.9 & 10.3 & 23 & 1.9 \\
\hline
\end{tabular}

1) Average of triplicates. 
These results indicate that the Zeiss Micro-Videomat, employing a maximum magnification of $1,500 \times$, does not adequately describe the number count and particle size distribution for colloidal particles (size less than $1 \mu \mathrm{m}$ ). The instrument is, however, sufficiently accurate for counting and sizing particles above the $1 \mu \mathrm{m}$ limit. Because the total surface area and mass (volume) concentrations depend predominantly on particles above this size, loss of the colloidal fraction can be tolerated. For problems concerning the transport and fate of potentially deleterious substances found in the colloidal fractions, more elaborate procedures are required (see eq. 16,17).

\subsection{Precision of counts with Zeiss Videomat}

Zürichsee water samples from the unchlorinated influent of the Water Treatment Plant Lengg were used to measure the counting precision of the Zeiss electronic counter. Samples were fixed with formaldehyde, stained and centrifuged. A total of six samples were counted, with 400 to 800 counts per sample. A summary of the precision of measured total particle counts and computed distribution parameters, as indicated by the coefficient of variation (CV), is presented in table 5 .

Table 5. Precision of particle counting using Zeiss Videomat.

Sample: Unchlorinated influent from 24 November 1975, Water Treatment Plant Lengg, Zürich. Sample concentration with impact centrifuge. Number of measurements: 6 .

\begin{tabular}{lrr}
\hline Summary parameters & Average & $\begin{array}{r}\text { Coefficient } \\
\text { of variation } \\
(\%)\end{array}$ \\
\hline Total number $\left(\mathrm{ml}^{-1}\right)$ & $1.18 \times 10^{5}$ & 10.8 \\
Total area $\left(\mathrm{cm}^{2} \mathrm{ml}^{-1}\right)$ & 0.118 & 16.0 \\
Total Volume $\left(\mathrm{ml} \mathrm{ml}^{-1}\right)$ & $4.7 \times 10^{-5}$ & 46.0 \\
\hline & & Coefficient \\
\hline Particle size distribution & Average & of variation \\
parameters & & 9.7 \\
Number length mean diameter $(\mu \mathrm{m})$ & 3.4 & 25.4 \\
Dispersion & 20.9 & 19.16 \\
Number volume mean diameter $(\mu \mathrm{m})$ & 9.0 &
\end{tabular}

* Computed assuming spherical particles.

Precision is good $(\mathrm{CV} \cong 10 \%)$ for total number counts and the number length mean diameter, but decreases for the computed total area and volume concentration, and the dispersion and number volume mean diameter of the distribution. The decreasing precision as parameters become nonlinearly dependent on particle size reflects the experimental errors associated with counting of the small number of large particles (d $>40 \mu \mathrm{m}, \Sigma \Delta \mathrm{N}_{\mathrm{i}}<0.1 \%$ of total particles, $\mathrm{CV}>90 \%$ ), as indicated in table 6 . 
Table 6. Precision of particle councing in each size class with Zeiss Videomat.

Sample: Unchlorinated influent from 24 November 1975, Water Treatment Plant Lengg, Zürich.

Number of measurements: 6.

\begin{tabular}{rccr}
\hline Class interval & Mean size & $\begin{array}{l}\text { Coefficient of } \\
\text { variation of } \\
\text { particle counts } \\
(\%)\end{array}$ & $\begin{array}{r}\text { Cumulative } \\
\text { percent by } \\
\text { number }\end{array}$ \\
\hline $0.3-0.425$ & $(\mu \mathrm{m})$ & 38.7 & 1.94 \\
$0.425-0.6$ & 0.36 & 26.6 & 6.44 \\
$0.6-0.85$ & 0.51 & 27.4 & 13.92 \\
$0.85-1.2$ & 0.725 & 27.6 & 26.59 \\
$1.2-1.7$ & 1.025 & 17.6 & 43.74 \\
$1.7-2.4$ & 1.45 & 12.3 & 59.92 \\
$2.4-3.4$ & 2.05 & 10.2 & 73.43 \\
$3.4-4.8$ & 2.9 & 8.7 & 82.77 \\
$4.8-6.8$ & 4.1 & 12.9 & 89.20 \\
$6.8-9.6$ & 5.8 & 14.2 & 93.60 \\
$9.6-13.6$ & 8.2 & 17.8 & 96.68 \\
$13.6-19.2$ & 11.6 & 30.2 & 98.77 \\
$19.2-27.2$ & 16.5 & 39.9 & 99.49 \\
$27.2-38.4$ & 23.2 & 38.0 & 99.82 \\
$38.4-54.3$ & 32.8 & 88.9 & 99.93 \\
$54.3-76.7$ & 46.3 & 245 & 99.98 \\
$76.7-108$ & 65.5 & 240 & 100 \\
\hline
\end{tabular}

\subsection{Comparison of alternative sample preparation techniques}

In many water treatment plants treating surface water, routine measurements of phytoplankton and detritus concentrations are made using the Utermöhi sedimentation method for sample concentration. Combining the sedimentation method with the Zeiss Micro-Videomat is straigthforward and only requires an inverted microscope. This combination could provide an additional and rapid method for surveillance of raw water quality and treatment plant performance with respect to particulate matter (minimum size $=1 \mu \mathrm{m}$ ). Thus, this method was compared with the centrifuge concentration method, using water treatment plant influent samples collected on three occasions.

For both sets of samples, triplicates were prepared, fixed with formaldehyde and stained with Gentiana-violet. $50 \mathrm{ml}$ samples were sedimented 24 hours, and $1.0 \mathrm{ml}$ samples were centrifuged at $1.800 \mathrm{rpm}$ for 30 minutes. A comparison of average total counts, and three PSD parameters are shown in tables 7 and 8, respectively.

Differences in number counts fall easily within experimental error and are statistically insignificant $(p=0.95)$. Some variations in the mean diameters, $d_{N L}$ and $d_{N v}$ as well as the dispersion were noted (see table 8 ), but differences were statistically insignificant $(p=0.95)$ with the exception of the sample of 17 November 1975. In this case, the presence of a few large particles (size $>20 \mu \mathrm{m}$ ) in the sedimented samples produced the statistically significant $(p=0.99)$ deviations.

For number counts, both systems give statistically equivalent results at a $95 \%$ confidence level. Potential variations in parameters of the distribution appear 
acceptable for routine measurements. It is concluded that either concentration technique can be employed in combination with an electronic image analyzer. The choice depends upon user preference and speed of sampling requirements.

Table 7. Comparison of particle number counts $\left(d_{1} \geqslant 0.3 \mu \mathrm{m}\right)$, sample concentration by centrifuge and by sedimentation (Number $\mathrm{ml}^{-1} \pm$ standard deviation).

\begin{tabular}{lrr}
\hline Sample date & Centrifuged samples ${ }^{2}$ ) & Sedimented samples $\left.^{3}\right)$ \\
\hline 27.10 .75 & 27,000 & 28,500 \\
& $\pm 1,900$ & $\pm 2,800$ \\
3.11 .75 & 23,700 & 24,300 \\
& $\pm 1,100$ & $\pm 6,300$ \\
17.11 .75 & 40,200 & 39,100 \\
& $\pm 5,600$ & $\pm 9,000$ \\
\hline
\end{tabular}

1) Samples: Unchlorinated influent, Water Treatment Plant Lengg, Zürich.

2) Particle counting using Zeiss Micro-Videomat.

3) Determination with Zeiss Micro-Videomat mounted on the inverted mircroscope.

Table 8. Comparison of Particle size distribution parameters for sample concentration with centrifuge (1) and sedimentation (2).

\begin{tabular}{lcccccr}
\hline Sample date & \multicolumn{2}{l}{$\begin{array}{l}\text { Length mean diameter } \\
(\mu \mathrm{m})\end{array}$} & \multicolumn{2}{l}{$\begin{array}{l}\text { Volume mean diameter } \\
(\mu \mathrm{m})\end{array}$} & Dispersion \\
\hline & Method & Method & & & & 2 \\
& 1 & 2 & 1 & 2 & 1 & 14 \\
\hline 27.10 .75 & 3.1 & 3.0 & 10.0 & 7.3 & 27 & \pm 4 \\
& \pm 0.4 & \pm 0.3 & \pm 2.4 & \pm 1.0 & \pm 10 & 26 \\
3.11 .75 & 4.6 & 4.1 & 11.0 & 10.0 & 34 & \pm 3 \\
& \pm 0.3 & \pm 0.7 & \pm 2.0 & \pm 1.0 & \pm 11 & 23 \\
17.11 .75 & 2.9 & 3.9 & 6.7 & 10.3 & 12 & \pm 6 \\
& \pm 0.2 & \pm 0.3 & \pm 1.2 & \pm 3.3 & \pm 4 &
\end{tabular}

1) Samples as in table 7 .

Numbers shown are averages of triplicates \pm one standard deviation.

\section{Summary and conclusions}

Use of the Zeiss Micro-Videomat electronic semiautomatic image analyzer for routine measurements of size distributions of particules found in natural waters greater than $0.3 \mu \mathrm{m}$ has been investigated. New sample preparation techniques were developed and evaluated in order to eliminate previously reported inaccuracies of particle counting with an image analyzer.

Concentrations of dilute suspensions $(<10 \mathrm{mg}$ TSS $/ \mathrm{l})$ with the traditional Utermöhl technique were compared with concentrations achieved with a Shandon-Elliot Cytocentrifuge operated at $1,800 \mathrm{rpm}(\sim 450 \mathrm{~g})$. The accuracy and precision of the scanning system was evaluated using water samples from the influent of the Water Treatment Plant Lengg, Zürich (withdrawal depth, $34 \mathrm{~m}$ ). Multiple counts of particles due to irregular contrast of phytoplankton cells were eliminated by staining the particles with solution of Gentiana-violet. 
Concentration of inorganic particles (silica and clay sediment) was unsuccessful with the impact centrifuge. However, for particulate matter from Zürichsee, differences in the two methods used in concentrating (sedimentation and centrifugation) were statistically insignificant $(p=0.95)$ with respect to total number counts and parameters of the particle size distribution. Frequency distributions showed excellent agreement. Results suggest that applicability of the centrifuge technique must be evaluated on a case by case basis.

Comparison of the particle size distribution (PSD) determined by eye with an inverted microscope and semiautomatically with the counter showed acceptable accuracy for particle sizes above $1 \mu \mathrm{m}$. The PSD of the colloidal fraction deviated substantially from the exponential form of the frequency distribution obtained with the microscope. The experimental error in number counts as determined by the coefficient of variation was about $10 \%$. The precision of computed parameters of the PSD decreased also for larger particles. This was due to uncertainities in particle counts caused by small particle numbers in classes larger than about $>27 \mu \mathrm{m}$.

Concentration of particles from lake samples prior to counting with an electronic image analyzer can be conducted using either an impact centrifuge, or the traditional Utermöhl sedimentation chambers. Differences in mean number counts and PSD parameters between three groups of water samples were statistically insignificant $(p=0.95)$. The centrifuge technique is rapid, but is less precise for the counting of larger $(>20 \mu \mathrm{m})$ particles which generally exhibit low number density in lake waters.

With appropriate sample preparation as described here an electronic image analyzer shows potential for routine surveillance of raw water quality at water treatment plants, and evaluation of treatment plant performance with respect to removal of particulate material with a size greater than $1 \mu \mathrm{m}$, as well as for specific investigations of ecological phenomena in natural waters.

\section{ZUSAMMENFASSUNG UND SCHLUSSFOLGERUNGEN}

Man untersuchte die Anwendbarkeit des halbautomatischen, elektronischen Bildschirmanalysators ZeissVideomat für die routinemässige Messung der Grössenverteilung von Teilchen grösser als $0,3 \mu \mathrm{m}$ in Proben von Oberfiächenwasser. Dabei wurden neue Präparationstechniken entwickelt und bewertet im Hinblick auf Ungenauigkeiten, welche, wie früher berichtet, beim Zählen von Teilchen mit Bildschirmanalysatoren auftraten.

Die Anreicherung verdünnter Suspensionen $(<10 \mathrm{mg}$ Trockengewicht per Liter) mit der UtermöhlSedimentationskammermethode wurde mit jener Methode verglichen, bei welcher die Shandon-ElliotZytozentrifuge (1800 U.p.m., 450 g) zur Anwendung gelangte. Die Genauigkeit des Scanningsystems wurde anhand von Rohwasserproben des Seewasserwerkes Lengg der Wasserversorgung Zürich (Entnahmetiefe $34 \mathrm{~m}$ ) bewertet.

Zur Verhütung einer Mehrfachzählung einzelner Teilchen - verursacht durch ungleichen Kontrast der Phytoplanktonzellen - wurden die Proben mit Gentianaviolett angerärbt.

Die Anreicherung von anorganischen Teilchen (Silikat- und Tonmineralsedimente) mit der ShandonZentrifuge war nicht erfolgreich. Trotzdem waren für die Teilchen des Zürichsees die Unterschiede der beiden Methoden (Anreicherung der Teilchen mit und ohne Zentrifuge) sowohl bei der Ermittlung der Gesamtpartikelzahl als auch bei den Parametern der Partikelgrössenverteilung statistisch unbedeutend $(p=0,95)$. Die Häufigkeitsverteilungen zeigten ausgezeichnete Ubereinstimmung. Die Resultate deuten darauf hin, dass die Anwendbarkeit der Zentrifugaltechnik von Fall zu Fall abgeklärt werden muss.

Der Vergleich der Partikelgrössenverteilungen (PGV), bestimmt mit dem umgekehrten Lichtmikroskop 
und dem halbautomatischen PartikelzähIgerät, zeigte genügende Genauigkeit für Teilchengrössen oberhalb I $\mu \mathrm{m}$. Die PGV kolloidaler Teilchen wichen wesentlich von der Exponentialform der Häufigkeitsverteilung, die mit dem Mikroskop erzielt wurde, ab. Der Fehler der Gesamtzahl, bestimmt durch den Variationskoeffizienten, betrug etwa 10\%. Die Genauigkeit der errechneten Parameter der PGV nahm auch für grössere Teilchen ab. Diese Abnahme der Genauigkeit wurde durch Unsicherheiten in der Teilchenzählung verursacht, die durch die niedrige Partikelzahl in Grössenklassen über $27 \mu \mathrm{m}$ bedingt wurde.

Die Anreicherung von Teilchen aus Seeproben, wie sie für die Zählung mit dem elektronischen Bildanalysator notwendig ist, kann entweder mit der Shandon-Zytozentrifuge oder mit der UtermöhlSedimentationskammermethode bewerkstelligt werden. Unterschiede in der mittleren Teilchenzahl und den GV-Parametern zwischen drei Gruppen von Wasserproben waren statistisch unerheblich $(p=0,95)$. Die Zentrifugationsmethode geht rasch, ist jedoch weniger genau beim Zählen von Partikeln, die grösser als $20 \mu \mathrm{m}$ sind, welche normalerweise in kleineren Konzentrationen im Seewasser vorkommen als kleinere Partikein.

Mit den hier beschriebenen zweckmässigen Probepräparationen stellt der elektronische Bildanalysator Zeiss-Videomat eine gute Möglichkeit dar für die Routineüberwachung von Rohwässern in Aufbereitungsanlagen für Oberflächenwässer und zur Abklärung der Wirksamkeit von Aufbereitungsanlagen im Hinblick auf die Entfernung von Teilchen grösser als $1 \mu \mathrm{m}$ als auch für spezielle Untersuchungen ökologischer Erscheinungen in Gewässern.

\section{RÉSUMÉ ET CONCLUSIONS}

Nous avons testé l'écran semi-automatique Zeiss Micro-Videomat pour les mesures routinières des distributions des tailles de particules supérieures à $0,3 \mu \mathrm{m}$. De nouvelles techniques de préparation ont été développées et évaluées afin d'éliminer préalablement les particules incertaines apparaissant sur l'écran.

La concentration de dilution-suspension ( $10 \mathrm{mg}$ poids sec par litre) avec la traditionnelle méthode de chambre à sédimentation Utermöhl a été comparée avec la méthode de centrifugation Shandon-Eiliot $(1800 \mathrm{t} / \mathrm{mn}, 450 \mathrm{~g})$. L'exactitude et la précision du «scanning system» ont été évaluées en utilisant des échantillons d'eau brute provenant de la station de pompage de Lengg, du service des eaux de Zurich (profondeur $34 \mathrm{~m}$ ).

Les échantillons furent préalablement colorés avec une solution de violet-gentiane ( 2 gouttes $/ 100 \mathrm{ml}$ ) afin d'éviter les erreurs de comptage causées par un contraste insuffisant et irrégulier des cellules du phytoplancton. La concentration des particules inorganiques (silicates et sédiments limoneux) par la centrifugation (Shandon-Elliot) ne donne pas de bons résultats. Quoique, pour les particules du lac de Zurich, les différences entre les méthodes utilisées (concentration des particules avec ou sans centrifugation) furent statistiquement insignifiantes $(p=0,95)$ et cela aussi bien dans le nombre total que dans les paramètres de distribution des particules. Les fréquences de distribution montrèrent d'excellentes concordances. Les résultats montrent que la validité de la méthode par centrifugation doit être évaluée dans chaque cas.

La comparaison de la distribution des tailles des particules (DTP), déterminée a l'aide d'un microscope inversé et avec l'appareil semi-automatique, montra une exactitude suffisante pour les tailles de particules supérieures à $1 \mu \mathrm{m}$. La DTP des particules collö̈dales dévia réellement de la forme potentielle de la fréquence de distributon obtenue avec le microscope. L'erreur du nombre total, déterminé avec le coefficient de variation, fut d'environ $10 \%$. La précision des paramètres des DTP calculés diminua également pour les particules les plus grandes. Cette diminution de précision était due à des incertitudes dans le comptage des particules et cela causé par un petit nombre de particules dans les classes de taille supérieures à $27 \mu \mathrm{m}$.

La concentration des particules dans des échantillons d'eau de lac doit être tout d'abord effectuée avec la méthode de centrifugation ou avec la traditionnelle méthode des chambres à sédimentation Utermöhl avant le comptage avec l'écran électronique. Les différences des nombres moyens des particules et des paramètres des DTP entre trois groupes d'échantillons sont statistiquement insignifiantes $(p=0,95)$. La méthode de centrifugation est rapide mais moins précise pour le comptage des particules supérieures à $20 \mu \mathrm{m}$ lesquelles apparaissent généralement en petit nombre dans l'eau des lacs. 
A l'aide des épreuves appropriées décrites ici, l'écran semi-ảutomatique Zeiss-Videomat'présente une bonne possibilité pour les surveillances routinières de la qualité de l'eau brute dans une station de pompage, ainsi que pour l'évaluation de l'efficacité des stations travaillant dans le but d'enlever les particules supérieures à $1 \mu \mathrm{m}$. Cet appareil peut être également utile pour les recherches sur certains phénomènes écologiques dans les eaux.

\section{REFERENCES}

1 Lerman. A., Lal, D., and Dacey, M.F.: Stokes Settling and Chemical Reactivity of Suspended Particles in Natural Waters. In: Suspended Solids in Water. Ed. R.J. Gibbs. Plenum, New York 1974.

2 Schubel, J.R., and Kana, T.W.: Agglomeration of Fine-Grained Suspended Sediment in Northern Chesapeake Bay. Powder Technol. 6, 9 (1972).

3 Hahn, H., and Stumm, W: The Role of Coagulation in Natural Waters. Am. J. Sci. 268 (4), 354 (1970).

4 Gordon, D.C.: A Microscopic Study of Organic Particles in the North Atlantic Ocean. Deep-Sea Res. 17, 175 (1970).

5 Kavanaugh, M.. and Vagenknecht, A.: Grundlagen zur Auswahl geeigneter Verfahren zur Beseitigung ungelöster Stoffe bei der Seew asseraufbereitung. GWA 55 (9), 554 (1975).

6 Utermöhl, H.: Zur Vervollkommnung der quantitativen Phytoplankton-Methodik. Mitt. int. Ver. Limnol., No.9 (1958).

7 Leslie, J., Devey, L., Memawar, M., Nauwerck, A., and Pickett, E.: A Comparison of Electronic Particle Counters and Inverted Microscope Methods for Counting Phytoplankton. Technical Report No. 394. Fisheries Research Board of Canada (1973).

8 Sheldon, R.W., Prakash, A., and Sutcliffe, W.H.: The Size Distribution of Particles in the Ocean. Limnol. Oceanogr. 17 (3), 327 (1972).

9 Gibbs. R. J. (Ed.): Suspended Solids in Water. Plenum, New York 1974.

10 Gahm, J.: Handbuch für die visuelle Messung mit dem quantitativen Fernsehmikroskop. Technical publication from Zeiss, Oberkochen, BRD.

11 Watson, P.: A Slide Centrifuge, an Apparatus for Concentrating Cells in Suspension onto a Microscopic Slide. J. Lab. Chem. Med. 68 (3) (1966).

12 Allen, T.: Particle Size Measurement. Chapman and Hall, 1968.

13 Herdan, G.: Small Particle Statistics. Academic Press, New York 1960.

14 Bader, H.: The Hyperbolic Distribution of Particle Sizes. J. Geophys. Res. 75 (15), 2822 (1970).

15 Brun-Cotton, J.: Stokes Settling and Dissolution Rate Model for Marine Particles as a Function of Size Distribution. J. Geophys. Res. 81 (9), 1601 (1976).

16 Lammers, W.T,: Biophysical Limnology: Separation of Suspended and Colloidal Particles from Natural Water. ES + T l (1), 52 (1967).

17 Murr, L.E., and Kloska. K.: The detection and Analysis of Particulates in Municipal Water Supplies by Transmission Electron Microscopy. Water Res. 10, 469 (1976).

Addresses of the authors: Dr. M.C. Kavanaugh, James M. Montgomery, Consulting Engineers, Inc., Walmut Creek, Calif., USA - Dr. U. Zimmermann. Wasserversorgung Zürich, Studienabteilung Limnologie, Postfach, CH-8023 Zürich, Switzerland. -- Mrs. A. Vagenknecht, Dipl.-Ing., Eidg. Anstalt für Wasserversorgung. Abwasserreinigung und Gewässerschutz (EAWAG), CH-8600 Dübendorf, Switzerland. 